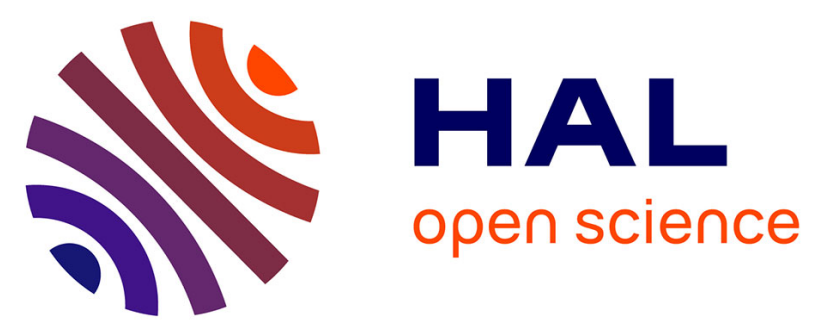

\title{
Cyclotella petenensis and Cyclotella cassandrae, two new fossil diatoms from Pleistocene sediments of Lake Petén-Itzá, Guatemala, Central America
}

Christine Paillès, Florence Sylvestre, Jaime Escobar, Alain Tonetto, Sybille Rustig, Jean-Charles Mazur

\section{To cite this version:}

Christine Paillès, Florence Sylvestre, Jaime Escobar, Alain Tonetto, Sybille Rustig, et al.. Cyclotella petenensis and Cyclotella cassandrae, two new fossil diatoms from Pleistocene sediments of Lake Petén-Itzá, Guatemala, Central America. Phytotaxa, 2018, 351 (4), pp.247-263. 10.11646/phytotaxa.351.4.1 . hal-02013950

\section{HAL Id: hal-02013950 https://hal.science/hal-02013950}

Submitted on 12 Feb 2019

HAL is a multi-disciplinary open access archive for the deposit and dissemination of scientific research documents, whether they are published or not. The documents may come from teaching and research institutions in France or abroad, or from public or private research centers.
L'archive ouverte pluridisciplinaire HAL, est destinée au dépôt et à la diffusion de documents scientifiques de niveau recherche, publiés ou non, émanant des établissements d'enseignement et de recherche français ou étrangers, des laboratoires publics ou privés. 
Cyclotella petenensis and Cyclotella cassandrae, two new fossil diatoms from Pleistocene sediments of Lake Petén-Itzá, Guatemala, Central America

CHRISTINE PAILLÈS ${ }^{1 *}$, FLORENCE SYLVESTRE ${ }^{1}$, JAIME ESCOBAR ${ }^{2-3}$, ALAIN TONETTO ${ }^{4}$, SYBILLE RUSTIG ${ }^{5}$ and JEAN-CHARLES MAZUR ${ }^{1}$,

1, Aix-Marseille Université, CNRS, IRD, Collège de France, INRA - CEREGE UM34, 13545 Aix en Provence, France

${ }^{2}$ Universidad del Norte, Km 5 Via Puerto Colombia, Atlantico, Colombia

${ }^{3}$ Smithsonian Tropical Research Institute, Balboa, Ancon, Republic of Panamá

${ }^{4}$ Aix-Marseille Université, Fédération de Chimie, PRATIM, 3 Place Victor Hugo, 13331 Marseille

Cedex 3, France

${ }^{5}$ Institute of Chemistry, Universität Potsdam, Karl-Liebknecht-Str. 24-25, D-14476 Potsdam, Germany

*Corresponding author. E-mail: pailles@cerege.fr 


\begin{abstract}
While analyzing the fossil diatom flora in one of the longest paleolimnological records (core PI-6) from Lake Petén-Itzá, lowland Guatemala, we encountered Aulacoseira Thwaites, Cyclotella (Kützing) and Discostella (Cleve \& Grunow) Houk \& Klee species appearing successively in the record. Among them, two new species that are assigned to the genus Cyclotella are described herein. Cyclotella petenensis sp. nov. is characterised by a coarse striation marked by a shadow line and a tangentially undulate central area with an arc of central fultoportulae. Cyclotella cassandrae sp. nov. has an elliptically shaped valve, coarse striae and a scattered ring of central fultoportulae in the central area. Classification and differences to similar taxa in the genus Cyclotella are discussed.
\end{abstract}

Key words: Diatom, Cyclotella, Pleistocene, Lake Petén-Itzá, Guatemala

\title{
Introduction
}

In the Yucatan Peninsula, the majority of fresh water bodies are alkaline, calcium bicarbonatedominated systems (Perez et al. 2013), and thus diatom valve preservation is usually poor (Metcalfe 2000). Paleolimnolgical records from the highlands in southern Mexico and Central America are rare (Metcalfe et al. 2015) particularly those based on diatoms (Habeyran et al. 2005, Slate et al. 2013). In the Yucatan Peninsula diatom records are generally confined to the Holocene (Whitmore et al. 1996, Metcalfe et al. 2009) whereas records spanning > 10, 000 years originate from Lake Zihuaren and Pàtzcuaron in the Mexico basin (Bradbury 2000, Ortega et al. 2010).

In 2006, the Petén-Itzá Scientific Drilling Project (PISDP) recovered a total of $1327 \mathrm{~m}$ of sediment from seven sites in Lake Petén-Itzá, Petén, northern Guatemala, for paleoclimate paleoenvironmental study (Hodell et al. 2006). The fossil diatom flora of Lake Petén-Itzá was analysed in core PI-6 dated by tephro-chronology and covering the last $84 \mathrm{Ka}$ (Kutterolf et al. 2016). An abundant and 
diversified flora was identified, in particular Stephanodiscaceae with Cyclotella meneghiniana Kützing, C. striata (Kützing) Grunow, Discostella stelligera (Cleve \& Grunow) Houk \& Klee as well as two new species of Stephanodiscaceae that we report here. Their classification within the genus Cyclotella is discussed.

\section{Materials and methods}

Sediment cores from Site PI-6 in Lake Petén-Itzá have a composite depth of $\sim 75.9 \mathrm{~m}$ and provide a continuous record of sediment accumulation for the last $84 \mathrm{cal} \mathrm{ka} \mathrm{(Hodell} \mathrm{et} \mathrm{al.} \mathrm{2008,} \mathrm{Muller} \mathrm{et} \mathrm{al.}$ 2010, Correa-Metrio et al. 2012, Escobar et al. 2012, Kutterolf et al. 2016). The PI-6 core chronology is based on 36 age/depth points generated from $44{ }^{14} \mathrm{C}$ dates on terrestrial remains and tephra layers dated by $\operatorname{Ar} / \operatorname{Ar}$ (Escobar et al., 2012). Fossil diatoms were subsampled at 10-cm intervals from 0 to 70 mcd (meters composite depth). The new diatom species reported were present between 17 and 60, 000 years.

Diatoms were prepared for analysis by oxidizing a five mm-thick slice of sediment $(0.5 \mathrm{~g})$ in hot $\mathrm{H}_{2} \mathrm{O}_{2}$ and $\mathrm{HCl}$ for two hours, rinsed several times with deionised water and cleaned samples stored in glass vials containing ethanol. Aliquots of cleaned diatoms were evaporated at room temperature on coverslips and mounted on glass slides using Naphrax ${ }^{\circledR}$ (Brunel microscopes). Diatoms were examined using light microscopy (LM) at $630 \times$ or $1000 \times$ magnification with a Nikon Eclipse $80 \mathrm{i}$ microscope equipped with differential interference contrast optics and a Nikon D300 camera. For scanning electron microscopy (SEM) observations, cleaned diatom material was air-dried on circular coverslips, attached to aluminium stubs, gold-coated with a Cressington 108 Auto Sputter Coater (Watford, UK) and examined using XL 30 ESEM Philips SEM at accelerating voltage of $25-30 \mathrm{kV}$. 
Descriptive terminology follows Anonymous (1975), Ross et al. (1979), Theriot \& Serieyssol (1994) and Håkansson (2002).

\section{Results}

The diatom record of core PI- 6 covers the last 84,000 years. The diatom flora is abundant and diverse and represented by 153 species that belong to 42 genera. Ninety-six species are extant and thrive in diverse waterbodies on the Yucatan Peninsula today (Perez et al. 2013). Throughout the sediment sequence, Aulacoseira, Cyclotella and Discotella species appear successively and dominated the flora. In particular we observed, in order of appearance, C. meneghiniana, Discostella stelligera, C. striata and two new species of Cyclotella that are described here.

\section{New species description}

\section{Division Bacillariophyta}

Class Coscinodiscophyceae F.R.Round \& R.M.Crawford in Round et al. 1990 emend Medlin \& Kaczmarska 2004

Order Thalassiosirales Glezer \& Makarova 1986

Family Thalassiosiraceae Lebour 1930

Genus Cyclotella (Kützing) Brebisson 1838

Cyclotella petenensis Sylvestre, Paillès \& Escobar sp. nov. (Figs. 1-9) 
Type: Lake Petén-Itzá, Department of Petén, Guatemala, Latitude $16^{\circ} 15^{\prime} 50$ N, Longitude $89^{\circ} 15^{\prime} 00$ W. Lacustrine sediment in Core PI-6, sample GLAD9-PET06-6A-13H2-98,3-99,3 cm (39.35 m below lake floor). Core collected in February 2006.

Holotype: slide PC0612192 and sediment PC0612194 deposited at the Laboratoire de Cryptogamie, Museum National Histoire Naturelle (MNHN) Paris, France.

Isotype: slides Zu/1094 and sediment R1278 deposited at the Friedrich Hustedt Diatom Study centre in Bremenhaven, Germany.

\section{Description}

Cells circular, drum-shaped, with a diameter between 15 and $60 \mu \mathrm{m}$. Central area tangentially undulate, representing one third to half of the valve surface. Central area occupied on the elevated part by two (for smaller specimens) to $>20$ valve face fultoportae in a semicircular arrangement, the depressed part appears unstructured or colliculate. The total number of central fultoportulae is strongly positively related with cell diameter. Marginal area circumferentially undulate with coarse striae of equal length, 5 to 9 within $10 \mu \mathrm{m}$. Marginal striation crossed circumferentially by a «ring» about two third of the valve surface, representing the transition between internal openings of alveoli and central lamina. Stria composed of a main row of large pori starting near the central part and continuing with a double row of smaller ones arranged in a quicunx (staggered). Central fultoportulae formed by a short tubulus surrounded by three satellite pores. Marginal fultoportulae (one tube +three satellite pores) on each costa. Rimoportula on a costa within in the ring of mantle fultoportulae.

\section{Notes}


Scanning electron microscopy reveals the valve centre is tangentially undulate (Fig. 11-12). On the raised part, the external openings of the central fultoportulae (CFP) lie in a semicircular position. On the unornamented depressed part, there are scattered granules and small depressions that ressemble pori, but do not penetrate the valve and are probably associated with granules on the opposing valve (Fig. 12).

Marginal striation appears complex: interstriae and striae are not clearly differentiated, giving the impression of no real interstriae (Fig. 13). A lateral view of the valve (Fig. 14) reveals that interstriae (ribs) are in the depressions, whereas the middle part of the striae are elevated. At the transitional central/marginal area, each rib is covered with a row of four to six large areolae. Halfway along the marginal area, the row of large areolae divides into two rows of smaller areolae arranged in quiqunx, separated by a very narrow strip of silica that covers the rib up to the valve edge (Fig. 15). Thus, the alveolar chamber (striae) is covered by two lateral rows of medium-sized areolae separated in the middle by a single row of very fine puncta that are slightly elevated (Fig. 16). On the mantle, this row of fine punctae is replaced by small granules. Similarly, the narrow strips of silica covering the ribs broaden and carry circular openings as the external expression of mantle fultoportulae (MFP). The valve face/mantle junction forms a gentle curve with no spines or spinulae. The valve mantle edge is covered with a narrow zone of granules (Fig. 16).

Internally, the alveoli represent one third of the valve diameter small in size and elongated. They are occluded with a marginal (centrifugal roofing) and central (centripetal roofing) laminae. CFP consist internally of a short tubulus surrounded by three satellite pores. The rimoportula (RM), is generally opposed to the arc of the CFP and protrudes well into the valve (Fig.17). It is located on a costa in the ring of MFP and consists of a stalked labium with a deflected end and a radial to slightly oblique slit (Figs 18-19). The MFP are borne on each costa, close to the edge of the valve (Fig. 18) 
and composed of a short tubulus surrounded by three satellite pores (Fig. 19). The external openings of MFP are close to the valve edge, round with a short tubulus (Fig. 20) that communicates with the inside of the valve through a narrow canal (Fig. 21). The cingulum consists of smooth and hyaline bands: an open valvocopula of the same width as the valve mantle (Fig. 12) and a single pleura (Fig. 22).

Etymology: The specific epithet petenensis refers to Lake Petén-Itzá the type location of the species. Time range: 50-20,000 years, but probably present in older sediments. Abruptly absent after the Last Glacial Maximum (LGM, ca 20,000 years) in Lake Petén Itzá. Also reported from Lake Tuxpan, México, around 600 years BC (K. Nooren, pers. comm.). Not present in modern surrounding waterbodies from the Yucatan Peninsula.

Cyclotella cassandrae Paillès \& Sylvestre sp. nov. (Figs 23-27)

Type: Lake Petén-Itzá, Department of Petén, Guatemala, Latitude $16^{\circ} 15^{\prime} 50$ N, Longitude $89^{\circ} 15^{\prime} 00$ W. Lacustrine sediment in Core PI-6, sample GLAD9-PET06-6A-13H2-98.3-99.3 cm (39.35 m below lake floor), core collected in February 2006.

Holotype: slide PC0612194 deposited at the Laboratoire de Cryptogamie, Museum National Histoire Naturelle (MNHN) Paris, France.

Isotype: slide Zu/1095 and sediment R 1278 deposited at the Friedrich Hustedt Diatom Study centre in Bremenhaven, Germany. 


\section{Description}

Elliptically shaped valves, diameter $24-46 \mu \mathrm{m}$ along major axis and 18-30 $\mu \mathrm{m}$ along minor axis.

Central area elliptical, slightly transversally undulated with scattered punctae (10 to 25) corresponding to the external opening of central fultoportulae. Central fultoportulae formed by a tube surrounded by two to three satellite pores. Marginal area about one third of valve surface circumferentially undulated with coarse to very coarse striae. Striae of unequal length and density: along major axis $8-12$ st/10 $\mu \mathrm{m}$, along minor axis 6-9 st/10 $\mu \mathrm{m}$ longer, more outspread and sometimes dichotomous. Striae formed by four to six rows of small rounded areolae $(30 \mathrm{in} 10 \mu \mathrm{m})$. Mantle fultoportulae present on nearly each costa and composed of one tube and three satellite pores. Rimoportula inserted on a costa within the ring of mantle fultoportulae. External openings of mantle fultoportulae and rimoportula in a ring at some distance from the valve margin.

\section{Notes}

Externally the central area appears smooth with several scattered CFP inserted on either the convex or concave part of the undulation (Figs 28-29). The striae are concentrically undulated with a steep mantle that is short and very finely punctated (Fig. 30). The interstria is a narrow band of silica bearing at the valve mantle junction, a simple rounded external opening of MFP (Fig. 31). These openings are located in a ring where the elongated external opening of the RM is inserted (double white arrow in Fig. 31), below the striation continues. No spines detected.

Internally, the RM is always inserted along the major axis of the valve (Fig. 32). CFP consist of one tube and two to three satellite pores (Figs 32, 36). Alveoli of unequal length and elongated with sometimes inserted costae, triangular in shape (Fig. 33). On nearly every other costae a MFP is present 
(Fig. 34) and formed by a central tube surrounded by three satellite cowlings (Fig. 35). Along the major axis, MFP are located just below the marginal lamina, whereas at the extremities (parallel to the minor axis) MFP are embedded in the costae at some distance from the valve margin (Fig. 36). Within the ring of MFP, one RM is situated on a costa close to the valve edge, with a short neck and an oblique slit (Fig. 37). Girdle bands partially present (Figs 38-39).

Remark: In the material examined there were mostly single valves with rare complete frustules with girdle.

Etymology: This taxon is named in memory of Cassandra Pattison, the beloved deceased daughter of Christine Paillès.

Time range: 41-39,000 years, abruptly absent thereafter, not present in modern water bodies of the Yucatan Peninsula.

\section{Discussion}

In LM, among Cyclotella species having a tangentially undulate central area with several central fultoportulae and coarse marginal striae, Cyclotella petenensis resembles C. meneghiniana Kützing, $C$. gamma Sovereign, C. quillensis Bailey, C. scaldensis Muylaert \& Sabbe, C. striata (Kütz.) Grun, C. litoralis Lange \& Syversten, C. stylorum Brightwell or C. desikacharyi Prasad (Table 1). The striking features of $C$. petenensis in LM are the presence of a « shadow line » in the marginal striation and few central fultoportulae arranged in an arc on the raised part of the central area. The «shadow line» is only present in C. gamma, C. quillensis and C. scaldensis whereas central fultoportulae arranged in an arc are a common feature of $C$. litoralis, $C$. stylorum and $C$. desikacharyi. The central areas of $C$. scaldensis, C. striata, C. litoralis, C. stylorum, and C. desikacharyi are, however, coarsely colliculate compared to the unstructured and slightly colliculate central area of $C$. petenensis. Marginal chambers 
are clearly visible in $C$. stylorum and $C$. desikacharyi, whereas they are absent in $C$. petenensis. In addition, the striae density in C. scaldensis, C. striata, C. litoralis, C. stylorum and C. desikacharyi is higher than in C. petenensis.

SEM photographs revealed that $C$. petenensis shares with C. gamma and C. quillensis not only the « shadow line » (Sovereign 1963, Lowe 1981, Battarbee et al. 1984) or degree of alveolar occlusion, but also the structure (one tube and three satellite pores) and the position of MFP, as well as a single well-developed RM, all located on costae within a ring. Only the number and position of CFP differ between these species: one to three CFP in C. gamma (Lowe 1981), one to nine CFP in an arc in C. scaldensis (Muylaert \& Sabbe 1996), and a ring of up to 60 CFP in C. quillensis (Battarbee et al. 1984). Although C. petenensis also shares the «shadow line» with $C$. scaldensis, it differs with respect to MFP which are located on each to every fourth costae in C. scaldensis. The striae structure near the central area consists of a single row of large areolae that gradually increase their numbers in rows towards the valve margin, a character shared by C. gamma and C. petenensis. In C. gamma, however, these large areolae are on radiating alveoli, whereas in $C$. petenensis they are on costae. In $C$. petenensis the presence of up to $20 \mathrm{CFP}$ arranged in an arc near the margin of the central area constitutes a constant, unique feature, the number of CFP being size-dependent (Fig.10). In the central area of C. scaldensis, C. stylorum, C. litoralis, and C. desikacharyi an arc of up to $12 \mathrm{CFP}$ on the convex part of the undulation is similar to that of $C$. petenensis. Nevertheless, in $C$. stylorum and $C$. litoralis the strong tangential undulation also affects the marginal striated zone, in contrast to $C$. petenensis. Additionally, C. stylorum and C. desikacharyi have internal marginal chambers that bear MFP on recessed or raised costae, whereas there are none in C. petenensis. The presence of MFP on every second to fourth costae and the tangential orientation of the RM in C. striata and C. scaldensis are also distinguishing morphological features. Furthermore, whereas C. meneghiniana, C. quillensis, 
C. striata and C. scaldensis have a spine close above the openings, C. gamma and C. petenensis have none.

C. petenensis shares at least one or more morphological features with each previously mentioned Cyclotella, but no taxon combines them all. Morphologically, $C$. petenensis is a unique combination of features from different species: C. quillensis, and C. gamma for the valve structure and C. litoralis, C. stylorum, C. scaldensis, C. caspia, and C. desikacharyi for the arc of CFP on the uplift of the central area. C. quillensis has been reported only from saline lakes (Battarbee et al. 1984). Bradbury (1971) also reported C. quillensis from Pleistocene sediments from Lake Texcoco in México. He also reported an undetermined species, Cyclotella sp. cf. C. stylorum, but unfortunately neither described nor illustrated it. Bradbury's reference to C. stylorum, whose characteristics under LM include a strongly tangentially undulated valve with CFP in an arc, suggest he could have identified C. petenensis under Cyclotella sp. cf. C. stylorum.

The unusual elliptical outline of Cyclotella cassandrae resembles that of C. rhomboido elliptica Skuja, but their fine morphology is markedly different. In LM, C. cassandrae is rather close to $C$. meneghiniana, C. gamma or C. quillensis, with coarse striae and a slightly transervally undulated central area with a variable number of CFP (Table 1) with $C$. cassandrae having a ring of CFP like $C$. quillensis. In contrast, SEM showed that $C$. quillensis possess alveolar chambers partially occluded by a central lamina, whereas $C$. cassandrae and C. meneghiniana have no central lamina. The structure of MFP is also very similar among the four species, arising from each mantle costae in C. quillensis, whereas some coastae lack them in C. meneghiniana, C. gamma and C. cassandrae. However, because of its elliptical shape, MFP in C. cassandrae are on the mantle along the major axis, whereas they are 
further in the costa on the valve face along the minor axis. In the four species, the RM is inserted within the ring of MFP and consists of a radially orientated labium.

Induced auxosporulation in clonal cultures of C. meneghiniana, C. gamma and C. quillensis revealed the difficulties in clearly identifying each of these morphologically similar species, as size range, position and number of CFP and position of MFP can vary during the life-cycle, both in cultured and natural populations (Meyer et al. 2001). Nevertheless, the elliptical shape, ring of CFP, absence of a central lamina, MFP on almost every costae, RM within the costae-borne MFP, both CFP and MFP formed by a tube and three satellite pores, consitute a unique combination of morphological features that allow C. cassandrae to stand as a new species.

\section{Classification, phylogeny and habitat}

In the last 40 years, the genus Cyclotella (Brebisson 1838:19) has received critical attention. There have been many attempts to classify species within the genus according to morphological features, by Lowe (1975), McFarland \& Collins (1978), Serieyssol (1981), Servant-Vildary (1986), Longinova (1981), Håkansson (1990, 1993), and Tanaka (2007). In a revision of the genus Cyclotella, Håkansson (2002) subdivided it on the basis of the type of undulation of the valve, the morphology of the central area, the position of the RM, and the position and number of satellite pores in MFP. Håkansson (2002) also transferred a few Cyclotella species to the newly created genus Puncticulata. She also suggested that the number of satellite pores on MFP may be more important for defining phylogenetic groups whitin Cyclotella. Interestingly, Loginova (1981) observed that only fossil Cyclotella species have MFP with three satellite pores. Under Håkansson's (2002) assumption, Prasad \& Nienow (2006) identified one lineage of Cyclotella with three satellite pores (C. meneghiniana, C. scaldensis, $C$. striata and C. desikacharyi) and another one with two satellite pores (C. atomus Hustedt, $C$. 
choctawhatcheena Prasad, C. baltica Grunow, C. litoralis and C. stylorum). Similarly, when using the presence/absence of a central lamina (Servant-Vildary 1986) and the presence/absence of marginal chambers (Lange \&Syversten 1989) they identified (1) a C. atomus/meneghiniana group for taxa with no central lamina, (2 ) a C. baltica/choctawhatcheena/litoralis/scaldensis group for taxa with a central lamina and no marginal chambers and (3) a C. striata/stylorum group for taxa with a central lamina and marginal chambers. Under these criteria C. petenensis belongs to group 2, whereas C.cassandrae belongs to group 1.

According to Khursevith \& Kociolek's (2012) diatom classification based on the structure of alveolae, number and location of RM, and the structure of striae, C. petenensis and C. cassandrae would belong to the morphological group C. meneghiniana complex . For Houk et al. (2010), the genus Cyclotella is subdivided into three groups and C. petenensis and C. cassandrae can be associated morphologically with group A, characterized by the presence of a tangentially undulate valve face, a central part without areolae and a rimoportula within the ring of MFP. A recent revision of the classification of the genus Cyclotella by Nakov et al. (2015) identified the position of the RM as a synapomorphy. Cyclotella, sensu stricto, has a RM located on a costa within the ring of MFP, as opposed to those of the Discostella, Lindavia and Tertarius genera (Nakov et al. 2015). After separating the genera Lindavia and Pantocsekiella from the genus Cyclotella on the basis of morphological and genetic characters, Acs et al. (2016) characterized the C. meneghiniana complex (including C. atomus, C. cryptica Reinmann et al., C. choctawhatcheena, C. distinguenda Hustedt, $C$. litoralis, C. quillensis and C. striata) by the shape and position of the RM - situated on the edge and arising from the mantle coastae internally.

Although Cyclotella is a predominantly freshwater genus (Round \& Sims, 1981), C. baltica, C. choctawhatcheena, C. desikacharyi, C. litoralis, C. meneghiniana, C. scaldensis C. striata and C. 
stylorum were identified as salt-tolerant species in coastal waters of Florida Bay (Prasad \& Nienow, 2006). The authors argued that salt tolerance arose at least twice in Cyclotella: once within the threepored forms (MFP with three satellite pores) and once with the two-pored forms and that the evolution of marginal chambers parallels the evolution of a true marine lifestyle. Based on DNA analysis, sequence alignment, parsimony and Bayesian analysis, Alverson et al. (2007) showed that the genus Cyclotella is polyphyletic and that marine and freshwater species were not distributed randomly across the phylogeny, implying that salinity presents a barrier to the spatial distribution of some diatoms. Out of the three clades identified, one lineage, including C. stylorum/C. striata (obligate marine), $C$. distenguenda (obligate freshwater) and C. meneghiniana/C.gamma (euryhaline species), revealed that two independent re-colonizations of the marine habitat from freshwater ancestors occurred, leading to at least two speciation events.

Following these different classifications schemes, it is evident that structurally $C$. petenensis and $C$. cassandrae can unequivocally be assigned to the genus Cyclotella as two new and distinct fossil species. C. cassandrae is an elliptically shaped C. meneghiniana, with no central lamina and a ring of CFP in the central area. In contrast, C. petenensis, with a central lamina, no marginal chambers, an arc of CFP on the raised part of the central area, MFP on each costa, and one RM within the ring of MFP and opposed to CFP, is an intermediate species between C. gamma and C. quillensis but related to $C$. striata and C. scaldensis. In Lake Petén-Itzá sediments, which cover the last 84,000 years, $C$. meneghiniana, Discostella stelligera, C. striata, C. petenensis and C. cassandrae appeared successively and dominated the fossil assemblages, suggesting changes in salinity (also confirmed by sub-dominant species). In a >46,000 years BP diatom record from lake Texcoco, México, Bradbury (1971), observed alternating dominance of Cyclotella sp. cf. C. stylorum (probably C. petenensis), $C$. 
quillensis and C. striata, reflecting changes in salinity. Bradbury noticed that their distribution throughout the core was a variation of « the same thing » such as ecotypes.

In the absence of genetic studies and relying only on morphological characteristics, it is likely that C. petenensis and C. cassandrae are variations of C. meneghiniana, present earlier in our record, and our succession may also suggest ecotypes variations or the early stages of speciation as populations adapt to varying conditions.

\section{Acknowledgements}

We thank the many agencies and individuals in Guatemala who assisted this project. They include: Universidad del Valle, Universidad San Carlos, Ministerio de Ambiente y Recursos Naturales, Consejo Nacional de Areas Protegidas, Instituto de Antro- pología e Historia, Autoridad Para el Manejo y Desarrollo Sostenible de la Cuenca del Lago Petén-Itzá, Wildlife Conservation Society, Alex Arrivillaga, Cathy Lopez, Margaret Dix, Michael Dix, Margarita Palmieri, David, Rosita, \& Kelsey Kuhn, and the staff at La Casa de Don David, Lico Godoy, Tony Ortiz, Franz Sperisen, Luis Toruño, Julian Tesucún, Melisa Orozco, Silja Ramirez, Gabriela Alfaro, and Jacobo Blijdenstein. We also thank the personnel of DOSECC (Drilling, Observation and Sampling of the Earth's Continental Crust) who were instrumental in obtaining the cores. We are indebted to Anders Noren, Kristina Brady and Amy Myrbo of LacCore (National Lacustrine Core Facility), Department of Earth Sciences, University of Minnesota-Twin Cities for their expertise in core acquisition, curation and sampling. This project was funded by grants from the US National Science Foundation, the International Continental Scientific Drilling Program, the Swiss Federal Institute of Technology, and the Swiss National Science Foundation. The financial support of Institute for Research and Development (IRD) is acknowledged. We are grateful to Mark Brenner and Jason Curtis for their helpful review. The 
authors also thank anonymous reviewers who help to improve the manuscript. First presented as a poster at $24^{\text {th }}$ International Diatom Symposium in Quebec City, Canada, 21-26 august 2016. 


\section{References}

Acs E., Ari E., Duleba M., Dressler M., Genkal S.I., Jako E., Rimet F., Ector L. \& Kiss K. (2016) Pantocseckiella a new centric diatom genus based on morphological and genetic studies. Fottea, Olomouc 16(1): 56-78.

Alverson A.J., Jansen R.K. \& Theriot E. (2007) Bridging the Rubicon: Phylogenetic analysis reveals repeated colonization of marine and fresh waters by thalassiosiroid diatoms. Molecular Phylogenetics and Evolution 45: 193-210.

Anonymous. (1975) Proposals for standardization of diatom terminology and diagnoses. Beihefte zur Nova Hedwigia 53: 323-354.

Battarbee R.W., Keister C.M. \& Bradburry J.P. (1984) The frustular morphology and taxonomic relationships of Cyclotella quillensis Bailey. In: Mann, D.G. (Ed.) Proceedings of the sixth international diatom symposium, Koeltz Scientific Books, Koenigstein, pp. 173-184.

Brebisson A. de (1838) Considérations sur les Diatomées et essai d'une classification des genres et des espèces appartenant à cette famille. Brée l'Ainé Imprimeur-Librairie, Falaise, 22p.

Bradbury J. P.( 1971) Paleolimnology of Lake Texcoco, Mexico. Evidence from diatoms. Limnology \& Oceanography 16(2): 180-200.

Bradbury J. P. (2000) Limnology history of Lago Pátzcuaro, Michoacàn, Mexico for the past 48,0000 years: impacts of the climate and man. Palaeogeography, Palaeoclimatology, Palaeoecology 163: 69-95.

Correa-Metrio A., Bush M.B., Cabrera K.R., Sully S., Brenner M., Hodell D.A., Escobar J. and Guilderson T. (2012) Rapid climate change and no-analog vegetation in lowland Central Amarica during the last 86,000 years. Quaternary Science Review 38: 63-75.

Escobar J., Hodell D.A., Brenner M., Curtis J.H., Gilli A., Mueller A.D., Anselmetti F.S., Ariztegui D., Grzesik D.A., Perez L., Schwalb A. \& Guilderson T.P. (2012) A 43-ka record of paleoenvironmental change in the Central American lowlands inferred from stable isotopes of lacustrine ostracods. Quaternary Science Reviews 37:92-104.

Habeyran K.A. \& Horn S.P. (1999) A 10,000 years diatom record from a glacial lake in Costa Rica. Mountain Research and Development 19(1): 63-70.

Håkansson H. (1990) Cyclotella meneghiniana Kütz. (Bacillariophyceae), its morphology and reappraisal of similar species. Beiheft zur Nova Hedwigia 100: 19-37. 
Håkansson H., Hadju H., Snoeijs P. \& Loginova L. (1993) Cyclotella hakanssoniae Wendker, and its relationship to C. caspia Grunow and other similar brackish water Cyclotella species. Diatom Research 8: 333-347.

Håkansson H. (2002) A compilation and evaluation of species in the genera Stephanodiscus, Cyclostephanos and Cyclotella with a new genus in the family Stephanodiscaceae. Diatom Research 17 (1): 1-139.

Hodell D.A., Anselmetti F.S., Brenner M. \& Ariztegui D. PISDP Scientific Party, (2006) The Lake Peten Itza scientific drilling project. Scientific Drilling 3:25-29.

Hodell D.A., Anselmetti F.S., Ariztegui D., Brenner M., Curtis J.H., Gilli A., Grzesik D.A., Guilderson T.J., Müller A.D., Bush M.B., Correa-Metrio A., Escobar J. \& Kutterolf S. (2008) An 85-ka record of climate in lowland Central America. Quaternary Science Reviews 27: 11521165.

Houk V., Klee R. \& Tanaka H. (2010) Atlas of freshwater centric diatoms with a brief key and descriptions. Part III. Stephanodiscaceae A. Cyclotella, Tertiarius, Discotella. Fottea 10 (supplement): 1-498.

Khursevich G. \& Kociolek J.P. (2012) A preliminary worldwide inventory of the extinct, freshwater fossil diatoms from the orders Thalassiosirales, Stephanodiscales, Paraliales, Aulacoseirales, Melosirales, Coscinodiscales and Biddulphiales. Beiheft zur Nova Hedwigia 141: 315-364.

Kutterolf S., Schindlbeck J.C., Anselmetti F.S., Aritzegui D., Brenner M., Curtis J., Schmid D., Hodell D.A., Mueller A., Pérez L., Pérez W., Schwalb A., Frische M. \& Wang K.-L. (2016) A 400-ka tephrochronological framework for Central America from Lake Petén Itzá (Guatemala) sediments. Quaternary Science Reviews 150: 200-220.

Lange C. \& Syversten E.E. (1989) Cyclotella litoralis sp.nov. (Bacillariophyceae) and its relationship to C.striata and C.stylorum. Nova Hedwigia 48(3-4) 341-356.

Loginova L.P. (1990) Classification of the diatom genus Cyclotella. In: Simola, H. (Ed.) Proceedings of the 10th international diatom symposium, Koeltz Scientific Books, Koenigstein, pp. 37-53.

Lowe R.L. (1981) The frustular morphology and distribution of Cyclotella gamma Sov. (Bacillariophyceae). Proceedings of Iowa Academy of Sciences 88(2): 82-84.

Lowe R.L. (1975) Comparative ultrastructure of the valves of some Cyclotella species (Bacillariophyceae). Journal of Phycology 11: 415-424. 
McFarland B.H. \& Collins G.B. (1978) A key to the species of the diatom genus Cyclotella (Kütz.) Bréb.based on new morphological data. Abstract, $26^{\text {th }}$ annual meeting of North American Benthological Society, Winnipeg, Mannitoba, 35 pp.

Metcalfe S.E., Barron J.A. \& Davies S.J. (2015) The Holocene history of the North American Monsoon: 'known knowns' and 'known unknowns' in understanding its spatial and temporal complexity. Quaternary Science Reviews 120: 1-27.

Metcalfe S., Breen A., Murray M., Furley P., Fallick A. \& McKenzie A. (2009) Environmental change in northern Belize since the latest Pleistocene. Journal of Quaternary Science 24(6): 627-641.

Metcalfe S.E., O’Hara S.L., Caballero M. \& Davies S.J. (2000) Records of Late Pleistocene Holocene climatic change in Mexico: a review. Quaternary Science Reviews 19: 699-721.

Meyer B., Wulf M. \& Håkansson H. (2001) Phenotypic variation of life-cycle stages in clones of three similar Cyclotella species after induced auxospore production. Diatom Research 16 (2): 343361.

Müller A.D., Islebe G.A., Hillesheim M.B., Grzesik D.A., Anselmetti F.S., Ariztegui D., Brenner M., Curtis J.H., Hodell D.A. \& Venz K.A. (2009) Climate drying and associated forest decline in the lowlands of northern Guatemala during the late Holocene. Quaternary Research 71: 133-141.

Muylaert K. \& Sabbe K. (1996) Cyclotella scaldensis spec.nov. (Bacillariophyceae), a new estuarine diatom. Nova Hedwigia 63 (3-4): 395-405.

Nakov T., Guillory W. X., Julius M.L., Theriot E. C. \& Alverson A.J. (2015) Towards a phylogenic classification of species belonging to the diatom genus Cyclotella (Baccilariophyceae): transfer of species formely placed in Puncticulata, Handmannia, Pliocaenicus and Cyclotella to the genus Lindavia. Phytotaxa 217 (3): 249-264.

Ortega B., Vàzquez G., Caballero M., Israde I., Lozano-Garcia S., Schaaf P. \& Torres E. (2010) Late Pleistocene: Holocene record of environmental changes in lake Zirahuen, Central Mexico. Journal of Paleolimnology 44: 745-760.

Pérez L., Lorenschat J., Schwalb A., Burkhard Scharf, Massaferro J., Paillès C., Sylvestre F., Hollwedel W., BrandorffG.-O., Brenner M., Islebe G. \& del Socorro Lozano M. (2013) Bioindicators of climate and trophic status in aquatic ecosystems of the northern Neotropics. Intrenational Journal of Tropical Biology 61(2): 603-644. 
Prasad A.K.S.K \& Nienow A. (2006) The centric diatom genus Cyclotella (Stephanodiscaceae:

Bacillariophyta) from Florida Bay, USA, with special reference to Cyclotella choctawhatcheeana and Cyclotella desikacharyi, a new marine species related to the Cyclotella striata complex. Phycologica 45(2): 127-140.

Ross R., Cox E.J., Karayeva N.I., Mann D.G., Paddock T.B.B., Simonsen R. \& C Sims P.A. (1979) An amended terminology for the siliceous components of the diatom cell. Beihefte zur Nova Hedwigia 64: 513-533.

Round F.E. \& Sims P.A. (1981) The distribution of diatom genera in marine and freshwater environments and some evolutionary considerations. In: Ross, R. (Ed.), Proceedings of the 6th international diatom symposium, Otto Koeltz , Koenigstein, pp. 301-320.

Servant-Vildary S. (1986) Fossil Cyclotella species from Miocene deposits of Spain. In: Ricard, M. (Ed.), Proceedings of the 8th international diatom symposium, Otto Koeltz, Koenigstein, pp. 495-511.

Serieyssol K. (1981) Cyclotella species of Late Miocene from St. Bauzile, France. In: Ross, R. (Ed.), Proceedings of the 6th international diatom symposium, Otto Koeltz, Koenigstein pp. 27-42.

Slate J.E., Jonson T.C. \& Moore T.C. (2013) Impact of pre-Columbian agriculture, climate change, and tectonic activity inferred from a 5,700-years paleolimnological record from lake Nicaragua. Journal of Paleolimnology 50:139-149.

Sovereign H.E. (1963) New and rare diatoms from Oregon and Washington. Proceedings of California Academy of Sciences 31(14): 349-368.

Tanaka H. (2007) Taxonomic studies of the genera Cyclotella (Kützing) Brebisson, Discotella Houk \& Klee and Puncticulata Håkansson in the family Stephanodiscaceae Glezer \& Makarova (Bacillariophyta) in Japan. Bibliotheca Diatomologica 53: 1-204.

Theriot E. \& Serieyssol K. (1994) Phylogenic systematics as a guide to understanding features and potential morphological characters of the centric diatoms family Thalassiosiraceace. Diatom Research 9 (2): 429-450.

Whitmore T.J., Brenner M., Curtis J.H., Dahlin B.H. \& Leyden B.W. (1996) Holocene climate and human influences on lakes of the Yucatan Peninsula Mexico: an interdisciplinary, palaeolimnological approach. The Holocene 6: 273-287. 
TABLE 1. Comparison of morphological features between the new fossil diatoms, Cyclotella petenensis and C. cassandrae, from lake Peten Itza and other extant Cyclotella species reported from the literature.

Abb.: +: present, np: not present, nd: no data, MA: major axis, mA: minor axis, cfp: central fultoportulae, mfp: marginal fultoportula, rm: rimoportula 


\section{FIGURE CAPTIONS}

FIGURES 1-9. Type material of fossil lacustrine diatom Cyclotella petenensis from lake Peten Itza, LM. (1-2) Valve view at two different focus showing striae and marginal alveoli representing the 'shadow line' and the tangentially undulated central area with cfp in an arc. (3-9) Size variation of C.petenensis with variable number of cfp related to valve diameter. (4) taken from holotype permanent slide PC0612192. Scale bar $=10 \mu \mathrm{m}$.

FIGURE 10. Correlation between valve size and the number of cfp in Cyclotella petenensis sp.nov.

FIGURES 11-16. Type material of fossil lacustrine diatom Cyclotella petenensis from lake Peten Itza, SEM. (11) External view of the valve face with a small central area and cfp positionned in an arc (white arrowheads), striae crossed by a 'shadow line' corresponding to the centripetal occlusion of the alveoli by the central lamina. (12) Oblique view of the valve showing two bands of the cingulum (white arrow). (13) Eroded part of the marginal area showing the limit between the central lamina and alveoli openings, erected ribs (costae) covered by the perforated silica layer with large areolae near the central area. (14) Side view of the valve with a gently sloping mantle, the dashed lines represent the interstriae/costae in depressions whereas the mid-part of striae is slightly elevated. (15) Details of striation near the valve margin (white arrows and dashed lines delineated the ribs). each striae being formed by two lateral rows of areolae separated by a narrow row of very fine areolae. (16) Detailed view of striation (dashed lines delineated the ribs): near the valve centre above the ribs rows of four to five large areolae separated by hyaline strips perforated by very fine areolae, on the valve face the rows of large areolae dividing up in two rows of smaller areolae arranged in quiqunx, the striae (between dashed lines) formed by two lateral rows of medium sized 
areolae separated by a finely perforated hyaline strip. Halfway the mantle the external openings of mfp (white arrowhead) and a larger rounded opening (double white arrowhead) representing the external expression of the rm slightly above the ring of mfp. Below the ring of external openings ( $\mathrm{mfp}$ and $\mathrm{rm}$ ) four to five rows of granules up to the valve margin. Scale $=10 \mu \mathrm{m}(10-11), 5 \mu \mathrm{m}(13), 2 \mu \mathrm{m}(12,14-15)$. Abbreviations. central fultoportulae (cfp), marginal fultoportulae (mfp), rimoportula (rm).

FIGURES 17-22. Type material of fossil lacustrine diatom Cyclotella petenensis from lake Peten Itza, SEM. (17) Internal view of the valve showing near the margins partially occluded alveoli by the central lamina, an arc of cfp (white arrowheads) consisting of one tube surrounded by three satellite pori in the central area and a single sessile rm (white double arrowhead) opposite to the arc. (18) Internal detailed view of the valve margin with $\mathrm{mfp}$ located on each costae and a stalked rimoportula with slightly deflected labium. (19) Internal view of costae-born mfp consisting of a tube surrounded by three satellite pores and the protruding rm with an oblique slit. (20) External view of the external openings of marginal fultoportula (white arrowhead) consisting of very short tubes separated by rows of very fine areolae and granules. (21) Detailed view of a broken valve margin showing a narrow canal connecting internal mfp to their external opening. (22) External view of two valves connected by a cingulum consisting of an open valvocopula (white arrowhead) and several copulae. Scale $=10 \mu \mathrm{m}(16,22), 5 \mu \mathrm{m}(21), 2 \mu \mathrm{m}(17-20)$. Abbreviations: central fultoportulae (cfp), marginal fultoportulae (mfp), rimoportula ( $\mathrm{rm})$.

FIGURES 23-27. Type material of fossil lacustrine diatom Cyclotella cassandrae from lake Peten Itza, LM. (23-24) Valve view at two different focus showing the elliptic shape of the valve, the slightly tangentially undulated central area with scattered puncta, short striae along 
the major axis, longer and apart striae along the minor axis and at some distance of the valve margin the external opening of mfp (black arrowheads). (25). Valve view with dichotomous striae along the minor axis. (26-27). Size variation of C.cassandrae: large specimen with dichotomous striae and a central area occupied by a scattered ring of puncta, some specimen are more rounded but still elliptic. Scale $=10 \mu \mathrm{m}$. Abbreviation: central fultoportulae (cfp), marginal fultoportulae (mfp), rimoportula $(\mathrm{rm})$.

FIGURES 28-33. Type material of fossil lacustrine diatom Cyclotella cassandrae from lake Peten Itza, SEM. (28) External valve view with cingulum elements, finely punctated short striae and a large elliptical central area slightly transversally undulated. (29) Valve view where the marginal striation is eroded and the central area occupied by a scattered ring of cfp. Lateral view of a valve with two girdle bands, the concentrically undulated marginal area and a steep mantle. (30) Detailed view of the valve margin with at least two pleural bands, on the valve face striae formed by four to six rows of very fine areolae alternating with narrow interstriae, on the mantle on each costae the rounded opening of $\mathrm{mfp}$, an oblong opening (white double arrowhead) representing the external expression of the rimoportula and below the ring of mfp-rm, striae and interstriae are equally finely punctated. (31) Internal view of a broken valve showing short and dense alveoli along the major axis, long and outspread alveoli along the minor axis, a protruding rimoportula generally located along the major axis, ringscattered cfp on both convex and concave parts of the central area. (32) Internal view showing inserted ribs/striae along the minor axis and $\mathrm{mfp}$ on nearly each costae. Scale $=5 \mu \mathrm{m}(28-29$, 31-32), $2 \mu \mathrm{m}$ (30). Abbreviations: central fultoportulae (cfp), marginal fultoportulae (mfp), rimoportula (rm). 
FIGURES 34-39. Type material of fossil lacustrine diatom Cyclotella cassandrae from lake Peten Itza, SEM. (34) Internal view of the valve margin along the major axis, mfp consisting of a short tube surrounded by three cowlings and located just at the tip of the costa below the marginal lamina. (35) Internal view of the valve margin along the minor axis where mfp are rather embedded in the costae at some distance of the marginal lamina and with triangularshaped inserted costae. (36) Oblique internal view of a broken valve showing mfp on nearly each costae, a single short costa-born rm and cfp consisting of a tube with two to three cowlings scattered indifferently on the convex and concave part of the central area. (37) Born on a costa, a detailed view of the rm consisting of a shortly stalked labium with a radially orientated slit. (38) External view of a complete corroded frustule where the two valves are attached by an open valvocopula (white arrowhead) and fragments of collapsed and eroded girdle bands. (39) Internal view of a valve with a large fragment of a stepped valvocopula, a broken rm (black arrowhead) and cfp consisting of one tube with two or three cowlings. Abbreviations: central fultoportulae (cfp), marginal fultoportulae (mfp), rimoportula (rm). 